\title{
THE HOUSE OF REPRESENTATIVES: "GRAND DEPOSITORY OF THE DEMOCRATIC PRINCIPLE"?
}

\author{
Joel Francis Paschal*
}

When Edmond Randolph opened the main business of the Philadelphia Convention on May 29, $\mathrm{I}_{7} 87$, he recited the usual criticisms of the Articles of Confederation; he then "proceeded to the remedy; the basis of which, he said, must be the republican principle." What Randolph meant in terms of political institutions appears quite clearly in the Virginia Plan he was about to propose. The whole governmental structure was to be founded on a popularly elected "first branch" of the legislature, which was to choose the "second" from nominees proposed by the state legislatures. The two together were to name the executive and the judiciary. By providing for the popular election of the "first branch," the Plan made the necessary recognition of the compelling notion of the sovereignty of the people. The House of Representatives stands today as the most obvious result of this recognition.

Massive changes were wrought, of course, in the scheme that Randolph offered. But the Convention, throughout its deliberations, clung to the Virginia resolve to suffuse the first branch with a democratic quality. It declined to sanction property qualifications for either electors or elected. It refused to subject new states to an inequality in representation. And it repeatedly approved the election of representatives by the people. In the discussions raised by the issue of popular election, we get the best idea of the framers' conception of the House of Representatives. There was some sentiment for election by the state legislatures. Roger Sherman, for example, complained that the people "want information and are constantly liable to be misled."2 Elbridge Gerry, deploring the "excess of democracy," offered only wavering support. ${ }^{3}$ Madison, James Wilson, and George Mason, however, voiced opposing views in the strongest possible terms. Madison was convinced that popular election was "essential," that "the great fabric to be raised would be more stable and durable if it should rest on the solid foundation of the people themselves. ..."4 Wilson likewise deemed popular election essential and added the thought that the legislature should be "the most exact transcript of the whole society." But the most significant statement was that of George Mason who projected a conception of the House of Representatives which has been preeminent from that day to this. As Madison has it, ${ }^{6}$

* B.A. I935, LL.B. 1938, Wake Forest College; M.A. 1942, Ph.D. I948, Princeton University. Member of the North Carolina bar.

${ }^{1} \mathrm{~V}$ The Debates of the Several State Conventions on the Adoption of the Federal Constitution as Recommended by the General Convention at Philadelphia in i 787 [hereinafter Etlior's Debates] $\times 27$ (Jonathan Elliot ed. 1937).

${ }^{2} I d$. at 136. $\quad{ }^{3} I d$. at I37.

${ }^{6} I d$. at 136. Later, Mason added: "The requisites in actual representation are, that the Representatives should sympathize with their constituents; should think as they think, and feel as they feel; 
Mr. MASON argued strongly for an election of the larger branch by the people. It was to be the grand depository of the democratic principle of the government ... It ought to know and sympathize with every part of the community, and ought therefore to be taken, not only from different parts of the whole republic, but also from different districts of the larger members of it; which had in several instances, particularly in Virginia, different interest and views arising from difference of produce, of habits, \&c. \&

Two further steps were taken to insure the democratic character of the House: (I) The provision requiring "apportionment among the several states . . . according to their respective numbers," and (2) the provision giving Congress ultimate control of "the times, places and manner of holding elections."8 The composition of the apportionment population was, of course, the subject of the great compromise of the Convention. In allowing three-fifths of the slaves to be included, the Convention made a necessary concession to the representation of property in the House. But the grand design of a House of Representatives springing directly from the people remained. And the adoption of the Thirteenth and Fourteenth Amendments removed the original blemish.

The language adopted in respect to Congressional control of elections reads as follows:

The times, places and manner of holding elections for senators and representatives shall be prescribed in each state by the legislature thereof; but the congress may at any time by law make or alter such regulations, except as to the places of choosing senators.

These words have provoked protracted controversy practically everywhere except on the floor of the Convention. It is true that the South Carolina delegates did make objection but they had not enough support to force a formal vote on this point. ${ }^{10}$ The Convention was, according to the later testimony of Roger Sherman, "very unanimous."11

The provision, first proposed to the Convention by the Committee on Detail, ${ }^{12}$ was explained by Madison in the following terms: $:^{13}$

The necessity of a general government supposes that the state legislatures will sometimes fail or refuse to consult the common interest at the expense of their local convenience or prejudices. The policy of referring the appointment of the House of Representatives to

and that for these purposes they should be residents among them." Id. at I6r.

That Representatives would be elected by districts appears to have been generally assumed at Philadelphia. Charles Cotesworth Pinckney asserted election by districts "must be the mode intended." Id. at 223 .

On the other hand, in the New York Convention, Melancthon Smith was apprehensive lest Congress should prevent election by districts. If this should happen, he argued, the "whole number of representatives might ... be taken from a small part of the state, and the bulk of the people, therefore, might not be fully represented." II Ellior's DeBates 327.

${ }^{7}$ U. S. Const. Art. I, \$2.

By abolishing slavery, the Thirteenth Amendment rendered the three-fifths clause inoperative. And the second section of the Fourteenth Amendment, by commanding that the "whole number of persons in each state, excluding Indians not taxed" be counted, expressly repeals the clause.

${ }^{10} \mathrm{~V}$ Elliot's Debates $40 \mathrm{I}-402$.

11 I The Debates and Proceedings in the Congress of the United States 800 (1834).

$12 \mathrm{~V}$ ELLiot's Debates 377.

${ }^{13} \mathrm{Id}$. at $40 \mathrm{O}-402$. (Italics supplied.) 
the people, and not to the legislatures of the states, supposes that the result will be somewhat influenced by the mode. This view of the question seems to decide that the legislatures of the states ought not to have the uncontrolled right of regulating the times, places, and manner, of holding elections. These were words of great latitude. It was impossible to foresee all the abuses that might be made of the discretionary power. Whether the electors should vote by ballot, or viva voce, should assemble at this place or that place, should be divided into districts; or all meet at one place, should all vote for all the representatives, or all in a district vote for a number allotted to the district,-these, and many other points, would depend on the legislatures, and might materially affect the appointments. ... Besides, the inequality of the representation in the legislatures of particular states would produce a like inequality in their representation in the national legislature, as it was presumable that the counties having the power in the former case would secure it to themselves in the latter.

This constitutes almost the entire discussion of Article I, Section 4 in the Philadelphia Convention. ${ }^{14}$ But when the new Constitution was submitted to public scrutiny, this section drew attention at once. ${ }^{15}$ The opponents of ratification charged that Congress had complete authority to make any regulation it might choose in respect to Congressional elections. ${ }^{16}$ In Pennsylvania, it was said that Congress might order the election for the entire state to be held in Pittsburgh. In Massachusetts, it was suggested that the place might be "Great Barrington or Machias." Property qualifications, inconvenient times of elections, and all kinds of plots by Congress to continue itself in power were imagined. The result of all this protest was that in six states, ${ }^{17}$ an amendment was proposed confining the power of Congress to those occasions when a state should neglect or refuse or be unable to act for itself. Two others, Massachusetts and New Hampshire, were willing for Congress to retain the authority in the above instances and also when the state legislature should make "reg-

\footnotetext{
${ }^{24}$ Earlier, when the manner of choosing the first branch was being considered, Charles Cotesworth Pinckney proposed election as the state legislatures might direct. Being defeated in this motion, he then moved for election "by the people in such mode as the legislatures should direct." Howcver, he abandoned this motion when it was "hinted that such a provision might be more properly tried in the detail of the plan." Id. at 223-224.

${ }^{15}$ Besides the numerous discussions in the various ratification conventions and those in The Federalist, Nos. 44, 59-61, see Noah Webster's Examination (which appeared in October, 1787), in Pave L. Ford, PAMPHLETS ON THE Constitution of the UNITED States 44 (1888). Webster asks: "What did the Convention mean by giving Congress power to make regulations, prescribed by the legislatures? Is this expression accurate or intelligible? But the word alter is very intelligible and the clause puts the election of Representatives wholly and the senators almost wholly, in the power of Congrcss.

"The views of the convention I believe to be perfectly upright-They might mean to place the election of representatives and senators beyond the reach of faction-They doubtless had good reasons, in their minds, for the clause. ..."

${ }^{10}$ Patrick Henry in the Virginia convention expressed his apprehensions as follows: "Congress is to have a discretionary control over the time, place, and manner of elections. The representatives are to be elected, consequently, when and where they please. . . . The power over the manner admits of the most dangerous latitude. They may modify it as they please." III Eulior's Debatrs 175-176. Samucl Nason in Massachusetts was equally extreme: "We now come, sir, to the $4^{\text {th }}$ section. Let us see: the time, place, and manner of holding elections, shall be prescribed in each state by the legislature thereof. No objections to this: but, sir, after the flash of lightning comes the peal of thunder. But Congress may at any time alter them," \&c. "Here it is, Mr. President: this is the article which is to make Congress omnipotent." II Ellior's DeBates r 35 -r 36.

${ }^{17}$ South Carolina, North Carolina, Virginia, Pennsylvania, New York, and Rhode Island.
} 
ulations subversive of the rights of the people to a free and equal representation" in Congress. ${ }^{18}$

The proposed amendments directly reflect the arguments used by the proponents of the Constitution. The Federalist, for example, asserted that Congress must have the ultimate power over elections or else Congress could be faced with the prospect of its own dissolution through the failure of the states to act, either because of neglect or inability. ${ }^{19}$ This argument was repeated in practically every ratifying convention, notably by Madison in Virginia. But Madison went on to argue that the power was also necessary in the event states should so act as to produce unfair and unrepresentative results. ${ }^{20}$ He referred particularly to the situation in South Carolina as did Rufus King in the Massachusetts convention. By the constitution of South Carolina, said King, ${ }^{21}$

the city of Charleston has a right to send thirty representatives to the General Assembly; the whole number of which amounts to two hundred. The back parts of Carolina have increased greatly since the adoption of their constitution, and have frequently attempted an alteration of this unequal mode of representation but the members from Charleston, having the balance so much in their favor, will not consent to an alteration; and we see that the delegates from Carolina in Congress have always been chosen by the delegates of that city. The representatives, therefore, from that state, will not be chosen by the people but will be the representatives of a faction of that state. If the general government cannot control in this case, how are the people secure?

Even in South Carolina, the Charlestonian Charles Cotesworth Pinckney assured the convention that it was "absolutely necessary that Congress should have this superintending power, lest, by the intrigues of a ruling faction in a state, the members of the House of Representatives should not really represent the people of the state. ..."22 There is also evidence of strong popular attachment to the provision. In Massachusetts, George Cabot told the convention: ${ }^{23}$

I am, sir, one of the people; such I shall continue; and, with their feelings, I hold "that the right of electing persons to represent the people in the federal government, is an important and sacred right." . . . for my own part, I confess that I prize the $4^{\text {th }}$ section as highly as any in the Constitution; because I consider the democratic branch of the national government, the branch chosen immediately for the people, as intended to be a check on the federal branch ... . and if the state legislatures are suffered to regulate conclusively the elections of the democratic branch, they may by such an interference, first weaken, and at last destroy, that check, they may at first diminish, and finally annihilate, that control of the general government, which the people ought always to have through their immediate representatives. As one of the people, therefore, I repeat that, in my mind, the $4^{\text {th }}$ section is to be as highly prized as any in the Constitution.

${ }^{18}$ See II EnLior's Debates ${ }^{777}$, for the whole of the Massachusetts amendment. The New Hampshire proposal was identical.

${ }^{10}$ No. 59 (Hamilton).

${ }^{31}$ II id. at 50-51. James Wilson also spoke of the possibility of a state making "improper" regulations which would require correction. See II id. at $44 \mathrm{r}$.

${ }^{22}$ IV EILIOT'S DEBATES 303. Pinckney's defense of this clause is all the more persuasive because of his prior opposition at Philadelphia. See note I4 supra.

${ }^{23}$ II Elitot's Debates 25-26. 
One further item is significant in the interpretation of Section 4. When the first Congress met, along with other amendments proposed, it considered one restricting the power of Congress over elections. Originally, it confined Congressional power to those occasions when the states should fail to act because of either neglect or inability. Later it was revised to take care of the case when a state might make an "improper" regulation. But even with this broad concession the proposal failed on the floor of the House. ${ }^{24}$

The foregoing review establishes conclusively that the well-understood purposes of the Philadelphia Convention in stipulating that Congress might "make or alter" regulations as to the times, places, and manner of Congressional elections were, at a minimum, to secure to Congress ( $\mathrm{I}$ ) the power to make any regulations a state might make, when a state, for any reason, should fail to act; and (2) the power to act when a state law should be subversive of an equal and fair representation. What measures Congress might take to achieve these purposes are not clear. As Madison said, the provision was in words of "great latitude." Madison did suggest to the Virginia Convention that "particular regulations" would be left to the state government and "general regulations" to Congress. ${ }^{25}$ But this was hardly more than a statement of policy. The truth of the matter is that no limits were discerned in the authority granted because none was suggested in the provision itself. The Senate was seen as some security against abuse but the chief trust was placed in the democratic process. ${ }^{28}$

\section{II}

Aside from the controversy over the method to be used, the legislative history of apportionment down to 1842 is notable chiefly for the steady growth in the size of the House of Representatives. ${ }^{27}$ The various apportionment acts, passed regularly every decade, contained only a simple listing of the number of representatives to which each state was entitled. The size of the House had been the subject of much contention in $x 787$ and $x 788$. Fears were frequently expressed that the 65 member

24 I The Debates and Proceedings in the Congress of the Unted States 797-800 (1834). Theodore Sedgewick proposed the retention of the power to deal with unsatisfactory state regulations, rcmarking that "as much injury might result to the Union from improper regulations, as from a neglect or refusal to make any." Id. at 800 . His suggestion was accepted with little opposition, although it was recognized that it left full power in Congress.

${ }^{25}$ III ElliotT's DeBates 367.

${ }^{28}$ The Federalist, Nos. 59-6r (Hamilton). In the Massachusetts convention tyrannicide was suggested as the proper expedient by Captain Isaac Snow. "Gentlemen have talked," he said, "about Congress moving the place of election from Georgia to the Mohawk river; but I never can belicve it. I will venture to conjecture we shall have some honest men in our Congress. We read that there were two who brought a good report-Caleb and Joshua. Now if there are but two in Congress who are honest men, and Congress should attempt to do what the gentlemen say they will, (which will be high treason,) they will bring a report of it; and I stand ready to leave my wife and family, sling my knapsack, travel westward, to cut their heads off." II Elliot's Debates 34.

${ }^{27}$ It should be mentioned that an apportionment bill was the target of the first presidential veto, partly on constitutional grounds. Besides objecting to the ratio employed in the bill, Washington thought it contrary to the provision limiting the number of Representatives to no more than one for every 30,000 . He reached this conclusion by applying the prohibition to each state individually. See Messiges AND Papers of the Presidents 124 (Richardson ed. I896). 
body established by the Constitution was so small that it could be easily subverted. ${ }^{28}$ And even if not, it was said that so small a number were utterly incapable of representing effectively the people of so vast a domain. The result was that a constitutional amendment was submitted to the states by the first Congress providing for an increase in the House to at least 200. ${ }^{29}$ The amendment not being ratified, Congress in 1792 set the membership at $105^{30}$ Thereafter, it was successively $14 \mathrm{r}, \mathrm{I} 83$, 212, and in $1830,243^{31}$ Despite this increase, the ratio likewise continued to grow, advancing from 33,000 in 1790 to 47,700 in 1830 . The apportionment bill passed in 1842 after the sixth census is unique in that it reduced, to 233 , the membership of the House. ${ }^{32}$

This bill's most notable feature, however, was its second section which read:

That in every case where a State is entitled to more than one Representative, the number to which each State shall be entitled, under this apportionment, shall be elected by districts, composed of contiguous territory, equal in number to the number of Representatives to which said State may be entitled; no one district electing more than one Representative.

As the first attempt by Congress to legislate under Article I, Section 4, this provision touched off a violent two-year controversy. The Congressional debates do not clearly reveal the political considerations which prompted Congress to act after more than fifty years of passivity. The measure was proposed by John Campbell, a Democrat from South Carolina, but the Whigs were its chief advocates, Campbell drawing practically no support from his Democratic colleagues.

It was said on the floor of the House that the new law was needed to thwart the growth of the general-ticket system, that single member districts had been assumed at the time of the Constitution, but that small states, perceiving a political advantage for themselves if all their representatives should be of the same party, had embraced the general-ticket system. The larger states, electing by districts and thereby returning a divided delegation, were then no more influential than the smaller ones. It was feared, therefore, if nothing was done, that the large states also would embrace the general-ticket system, and thus convert the House of Representatives to an assemblage of the states and not the people as originally intended. ${ }^{\mathbf{3 3}}$ Opponents of the bill countered with the assertion that the Whigs were motivated only by a desire to add to their representation.

The bill, while it would have affected all the states, bore most heavily on Alabama, Georgia, Mississippi, Missouri, New Hampshire, New Jersey, and Rhode Island, where the general-ticket system prevailed. Something of a crisis was precipitated when four of these states, Georgia, Mississippi, Missouri, and New Hamp-

\footnotetext{
${ }^{28}$ The question was thoroughly debated at Philadelphia and in the various state conventions. The debate in New York, led by Melancthon Smith on one side and Hamilton on the other, is as full as any. See II Elliot's Debates 243-260. See also The Federalist, Nos. 55-57 (Hamilton).

29 I STAT. 97 ( 1789$)$.

so I STAT. 253 (I792).

312 Stat. 128 (1802), 2 Stat. 669 (I8II), 3 Stat. 65I (I822), 4 STat. 516 (I832).

${ }^{32} 5$ STAT. 491 (1842).

${ }^{33}$ Cong. Globe, 27th Cong., 2d Sess. App. 343, 493, 513 (1842).
} 
shire, refused to bow to what was called the Congressional "mandamus." In the election of $\mathrm{I} 842$, these states persisted in the general-ticket system and the Twentyeighth Congress was faced with the problem of dealing with their recalcitrance. ${ }^{\mathrm{a}}$ While the ultimate result had already been determined by the return of the Democrats to power, ${ }^{35}$ elaborate constitutional justifications were offered by each side, as had been the case when the bill was passed. ${ }^{30}$

The argument of the opponents of the bill centered on two propositions: (I) that Congress had no authority except when a state had failed to make any provision at all for the election of representatives; and (2) that, admitting that Congress had the authority, it must exercise it completely and not call on the states for ancillary legislation. The first proposition was sustained by an outrageously

${ }^{34}$ Several of the states, while adhering to the district system, adopted resolutions denouncing the interference of Congress. See, e.g., the resolution in New York of September 5, I842, and that of Ohio of December 26,1842 when Congress was assured that if Ohio did district, "it will not be through any assent to the power assumed."

${ }_{35}$ "Mr. Kennedy [of Indiana] said that ... he would venture to make one prediction, and that was, when the vote came to be taken, all the Whig members would vote against the gentlemen who were elected under the general ticket system, and all the democratic members would vote for them. He saw no use in a protracted discussion." Cong. Globe, 28th Cong., Ist Sess. 240 (1844).

${ }^{36}$ The opponents of the bill argued, among other things: (I) That the supervisory power was limited to a very narrow construction of the term "holding elections," so that it was the mcthod of voting which Congress could control; (2) that perhaps a general-ticket system was the only constitutional arrangement in that the Constitution said (Art. $\mathrm{I}, \$ 2, \mathrm{cl} . \mathrm{I}$ ) that "The house of representatives shall be composed of members chosen every second year by the people of the several states"; and (3) that Congress could no more require districts for representatives than it could prescribe that scnators be chosen by localized groups of state legislators, Congress having the same power in both instances.

Garrett Davis of Kentucky answered the last two of these arguments as follows:

"Among the fundamental provisions of that instrument [the Constitution] are "The House of Representatives shall be composed of members elected every second year by the people of the scveral Statcs,' \&c.; and 'The Senate of the United States shall be composed of two Senators from cach State, chosen by the Legislatures thereof for six years,' \&c. It has been lately assumed, that the clause relating to the House of Representatives establishes the general ticket as the mode by which its members are to be elected; and this strange position it has been attempted to enforce by a more strange argument, deduced from the one concerning Senators. The plain object of these two provisions is to establish the body of electors of the two Houses, and not to prescribe the manner of choosing their members. But the argument is this: that the members of the State Legislatures cannot be divided into two classes, and the election of a Senator be assigned to each; and as the people of the States are to clect their Representatives, they cannot be divided into districts, and those residing in a district be restricted to vote for a single Representative, but all have the right to vote for all the Representatives of the State. If such reasoning be entitled to a serious answer, it may be said that Senators are not to be chosen by the members of the State Legislatures, but by the Legislatures; and the body of the two Houses must be convened and organized in General Assembly to constitute a Legislature. On the other hand, Representatives are to be elected, not by the States, but by the people of the States; and these phrases are to be recived as they were universally understood when the constitution was formed; and the right created by them may be exercised in the form in which ever since, until the present time, it has been recognized to exist by all. The people of the States, respectively, then elected, as they now do, the most numerous branch of their Legislatures; yet the whole people never voted for all the members of which it consisted, nor, indecd, for as many candidates. The position that the Hotse of Representatives must be chosen by all the people of the several States, would prove too much for the purposes of its advocates. If the mode of electing Representatives is to be deduced from this clause of the constitution, it establishes one much bejond the general ticket-it results, inevitably, that all the people of a State must not only vote for as many persons as it may be entitled to have Representatives, but each Representative must be chosen by the whole people. A majority, barely more numerous than the minority, voting by general ticket for as many persons as the number of Representatives of a State, would not be all the people of such State voting for, much less choosing all her Representatives." REPORT OF THE MiNORITY, H. R. REP. No. 60, 28th Cong., Ist Sess. 2-3 (1844). 
partial review of the ratification proceedings. The passages from The Federalist and Elliot's Debates giving color of support were quoted in full while contrary opinion was blandly ignored. Nathan Clifford, later a Supreme Court Justice, was one of the chief offenders in this respect. Clifford weakly contended that amendments were proposed "out of abundant caution to guard against the danger of misconstruction," and that they failed only because assurance was given that the power would be used solely to prevent the government's dissolution. ${ }^{37}$

The second proposition was advanced most strongly by Stephen A. Douglas, making his first appearance on the national stage. Douglas was the author of the report of the Elections Committee to which the case of the general-ticket representatives was referred. The Committee offered the following resolution: $:^{38}$

That the second section of "An act for the apportionment of Representatives among the several States, according to the sixth census," approved June 25, 1842 , is not a law made in pursuance of the Constitution of the United States, and valid, operative, and binding upon the States.

In the Committee report, Douglas went so far as to acknowledge that Congress might act, not only when the states neglected to do so, but whenever they acted "in such a manner as would subvert the rights of the people to a free and fair representation." But, he was quick to add, Congress had no "authority to instruct the State Legislatures in respect to the manner in which they shall perform the duties imposed upon them by the Constitution." Douglas pointed out that the law of 1842 did not ${ }^{39}$

district the States, nor provide for an election by general ticket; does not prescribe the mode of voting; does not fix the times, places, or manner of holding elections; does not make such alterations in the State laws, or enact new ones, which would enable the people to elect their Representatives. It is entirely nugatory and inoperative without the aid of State legislation....

Congress, he argued, must make provision for the execution of its own laws without commanding the states to come to its aid. Otherwise the great evil of the Articles would be revived. There would be unendurable collisions between the Federal and State Governments. The great aim of the Constitution, said Douglas, was to prevent such collisions by assigning the two sovereignties to separate and distinct spheres. Only by adherence to this "grand fundamental principle" could the Union be preserved.

The answer to Douglas and his followers was delivered by Garrett Davis of Kentucky. His report quotes enough of what was said and done at the time of the ratifications to show the almost limitless power which practicaly everyone assumed

${ }^{37}$ Cong. Globe, 27th Cong., 2d Sess. App. 349 (1843). The only clear support for this argument which I have found is Madison's statement in The Federalist, No. 44 at 357 (Hamilton I866): ". . . the election of the House of Representatives ... . will, probably, for ever be conducted by the officers, and according to the laws of the States."

${ }^{38}$ Relative to the Right of Members to Their Seats in the House of Representatives, $H$. REP. No. 60, 28 th Cong., Ist Sess. Io (1844).

so. at 5-6. 
Congress had been granted. And it met head on the Douglas sophistry of Congress being unable to prescribe the limits of state action.

Congress could, in truth, whenever it chose, regulate place ${ }^{40}$

and in that way limit the discretion of the Legislature ... It may regulate time or manner only; or under the head of manner, it may declare the way in which votes shall be given; or it may change, where it prevails, the majority principle to that of the plurality ... When Congress acts there are not two distinct and independent systems of legislation, it becomes one; . . . and any alteration it may make of the State laws has the identical effect it would have if made by the State Legislature.

The capital answer to Douglas came when Davis reminded Congress that the first section of the Act of 1842 was just as incapable of self execution as the second. There Congress had changed the representation of many states. Such a change was equally restrictive on legislatures and the constitutional obligations to implement the two sections were precisely identical. This idea had been stated with great force two years earlier by John Quincy Adams in a committee report provoked by President Tyler's expression of doubt of the constitutionality of the Act. The President admitted, said Adams, ${ }^{41}$

that the power of Congress, by law, to alter State regulations respecting the manner of holding elections for Representatives, is clear; but he has felt deep and strong doubts of the power to command the States to make new regulations, or alter their existing regulations.

This objection would invalidate every apportionment act which has been prescribed by Congress during the existence of the Government. Every new apportionment act not only annuls the regulations provided, by the laws of the several States, to hold elections of Representatives under the preceding apportionment, but is mandatory to the States to provide regulations for holding the elections within the State, conformably to the new apportionment law enacted by Congress. In every successive apportionment law, the number of Representatives in this House which many of the states have been entitled to send during the preceding ten years is increased or diminished; and the numerous State Legislatures which have been so long waiting for the legislation of Congress at this time and on this subject, the special extraordinary sessions which more than one of those Legislatures have been under the necessity of holding, have all been caused by their indispensable duty to provide regulations for giving effect to the mandatory injunctions of the congressional law.

The objection to the mandatory character of the law has an aspect so extraordinary as to be somewhat whimsical, when we consider that the power in Congress, admitted by the President to be clear, of districting the State by its own authority, is much heavier and more searching in its operation than that which he considers as so questionable. The election of Representatives to the national Legislature is not a burden, but a precious privilege. The geographical division of the territory of the State, according to the number of the Representatives allowed to the State in this House, is an operation obviously better suited to the action of the local Legislature than to that of the assembly representing the whole Union. The assignment of that operation, therefore, to the State Legislatures, though mandatory in form, is in substance a concession of power; and it is strange, pass-

${ }^{\circ}$ Report of the Minority, H. R. Rep. No. 60, 28th Cong, ist Sess. il (1844).

${ }^{11}$ H. R. REP. No. 909, 27th Cong., 2d Sess. 9-10 (1842). 
ing strange, to find even the most zealous and most jealous vindicator of State rights complaining of an investment of authority in the State as a grievous usurpation of authority of Congress.

For all the bluntness of the Douglas resolution, the result of the controversy in terms of constitutional interpretation was inconclusive. The Democratic majority, rather than formally declaring invalid the Act of $I 842$, contented itself with permitting the general-ticket representatives to serve out their terms. ${ }^{42}$ And, although the requirement for election by districts was on the statute books for nearly ninety years, Congress never denied seats to representatives elected at large. In this view, it might be argued that the 1842 Act was, as Douglas said, null and void. On the other hand, Congress repeatedly manifested a conviction that it had the power involved. In $\mathbf{1 8 6 2}$, it again called for election by districts of contiguous territory. ${ }^{43}$ In 1872 , it added the requirement that districts should contain "as nearly as practicable" equal numbers of inhabitants. ${ }^{44}$ Similar provisions were incorporated in the decennial apportionment statutes through $\mathrm{x} 9 \mathrm{I}{ }^{4},{ }^{45}$ and until the Supreme Court ruled that the 1929 Act, $^{46}$ by failing to repeat the customary provisions, had abrogated them, the requirements were generally supposed to be in effect. ${ }^{47}$ Furthermore, on the question of the validity of the 1842 statute and its successors, the Supreme Court in 1879 plainly indicated in ex parte Seibold that the partial quality of the Congressional action would not render it unconstitutional. ${ }^{48}$

Indeed, except for the Douglas report of 1844 , only one other voice with any authority in the premises has set any recognizable limits on the power of Congress over Congressional districts. In the contested election case of Davison v. Gilbert in Igor, a House Committee went much further than Douglas. Whereas Douglas practically conceded that Congress might occupy the whole field, laying off districts itself, the rgor committee denied the legality of any such action. But it laid more stress on the policy argument that it would be unwise for Congress to exercise such control. ${ }^{49}$

To summarize, the history of Article I, Section 4 in the Constitutional Convention, the understanding in the various states when the Constitution was ratified, and the subsequent legislative experience all lead to the conclusion that Congress may pass any law in respect to Congressional districts that a state legislature may pass. The only time this authority has ever been seriously challenged was in the struggle pro-

"2 Cong. Globe, 28th Cong, Ist Sess. 278-280 (1844). At least three of those whose seats were contested later attained prominence-Jacob Thompson of Mississippi, Howell Cobb and Alexander Stephens of Georgia. Stephens made the strange argument that, while he did not believe himself entitled to his seat, it was really a matter for the House, not him, to decide. He would therefore retain his seat until the House acted. His speech against his right to be present is reported with maddening incompleteness. See id. at 253-254.

${ }^{6} 12$ STAT. 572 (1862). "t 17 STAT. 28 (1872).

${ }^{45}$ See 22 Stat. 5 (I882), 26 Stat. 735 (I891), 3I Stat. 733 (I90I), and 37 Stat. I3 (I9II).

10 46 STat. 26 (1929).

47 Wood v. Broom, 287 U. S. x (1932). ${ }^{48}$ Ioo U. S. 371,384 (1879).

${ }^{19}$ H. R. REp. No. 3000, 56th Cong,, 2d Sess. (1901). Quite a different view was taken by the House Committee a few years later in the case of Parsons v. Saunders, H. R. ReP. No. I695, 6rst Cong., 2d Sess. (1909). 
duced by the 1842 statute and even there it was conceded that Congress itself might district the individual states. Nor does there seem to be any constitutional barrier to Congress exercising its power in respect to a single state only. Congress has made regulations in respect to the time of Congressional elections applicable to particular states. ${ }^{50}$ Indeed the grant of authority in no way circumscribes Congress. It may "make or alter" as it pleases. Moreover, it seems clear that the framers expected Congressional action directed at a single state. It certainly was not anticipated that there would be a general failure on the part of the states to provide the Congress with Representatives but rather that now and then one state might fail to do so. Nor was it anticipated that all the states would make improper regulations. Madison and King referred to a specific problem and their discussion clearly leaves open the inference that it would be dealt with specifically. And James Wilson took much the same view in the Pennsylvania convention..$^{51}$

Three other constitutional issues, all rendered moribund by events, have arisen in the legislative history of apportionment. One has to do with whether or not a new apportionment is commanded by the Constitution after each census. There was no question at all about this for the first one hundred and thirty years of our Government. But when certain Congressmen were stung by the public criticism over the failure of Congress to provide for a new apportionment after the 1920 census, the argument was repeatedly made that there was no constitutional duty to apportion every ten years. This argument was supported by a close reading of Article I, Section 2. It was said that the ten-year provision was mentioned only in connection with the census, and that no time limit was attached to the apportionment provision. This position was disputed, of course, and even its adherents conceded that there was a pressing compulsion for decennial action. ${ }^{52}$

Politically more potent but even less respectable constitutionally is the position that Congress may exclude aliens from the enumeration. This has been frequently proposed and many Congressmen have ruefully affirmed that only the barrier of the Constitution itself prevented their acceptance of the proposal. Others have resorted to the most tortured arguments to avoid the clear words of the Fourteenth Amendment: "Representatives shall be apportioned among the several states according to their respective numbers, counting the whole number of persons in each state, excluding Indians not taxed." The easiest answer to any argument on this question is provided in the history of the adoption of the Fourteenth Amendment. At that time, a determined effort was made constitutionally to exclude aliens from the

${ }^{50}$ I7 STAT. 578 (1873), I8 STAT. 78 (1874).

52 "I have heard it surmised by the opponents of this Constitution, that the Congress may order the election for Pennsylvania to be held at Pittsburg, and thence conclude that it would be improper for them to have the exercise of the power. But suppose on the other hand, that the assembly should order an election to be held at Pittsburg; ought not the general government to have the power to alter such improper election of one of its own constituent parts?" II Elliot's Debates 44I.

62 Among others, Senator (now Mr. Justice) Black denied that a decennial reapportionment was mandatory. See 7o Cong. Rec. 4553 (1929), 71 Cong. Rec. 1846 (1929). In defense of the failure to reapportion after the 1920 census, it was afterwards charged that the enumeration then did not correctly give the true population figures. 
enumeration. But the effort failed and the Amendment was deliberately worded to force the continued inclusion of aliens. ${ }^{53}$

Finally, it was strenuously contended in the 1920's that Congress could not constitutionally delegate to the president the authority to make the decennial apportionment. Actually, this feature of the 1929 law contained nothing new in principle. The Act of $185^{\circ}$ had instructed the Secretary of the Interior to do the same thing, subject, of course, to a Congressional veto. This Act, like its r929 offspring, required only a mathematical calculation in a prescribed manner. Although the $185^{\circ}$ delegation was hardly challenged at all on constitutional grounds, those opposed to the rg29 law, in their desperate struggle to prevent its enactment, made much of the point. One of the most vocal of them was Senator Black. He asserted that the law embodied a principle "which the Anglo-Saxon race has been fighting since its beginning," that it was to Congress that the power to apportion was confided by the Constitution, and that to place it in the hands of the president would clearly violate that instrument. ${ }^{54}$ The thirty-year acquiescence in presidential apportionment indicates the insubstantial nature of these contentions.

\section{III}

Quite naturally, sufferers from grossly unfair apportionments have turned to the courts for relief. Their pleas have been founded first on an allegation that an act of Congress has been violated by the questioned apportionment ${ }^{55}$ and more lately on the contention that the Constitution itself forbids an extreme inequality in Congressional districts. ${ }^{56}$ Giving urgency to such appeals is the argument that for all practical purposes, only the courts can generate the will to enforce a measure of

${ }^{53}$ Horace E. Flack, The Adoption of the Fourtennth AMendment 99-I27 (1908). If Cole Blease's estimate of the situation in 1929 was correct, the north-eastern states would have lost 35 representatives by the exclusion of aliens from the apportionment population. See 71 CoNG. Rrc. x710 (I929). A move to this effect was supported by Senator Black. See 7 I Cong. REc. 2065 (I929).

"7r CoNG. REc. 1612 (1929).

wood v. Broom, 298 U. S. I (r932). This was an appeal from the District Court in Mississippi which had enjoined Mississippi officials from conducting elections under a recent Mississippi districting act. The lower court found that the act did not provide districts approaching the IgI I Congressional standard of equal numbers "as nearly as practicable." The Supreme Court dissolved the injunction and ordered the complaint dismissed on the ground that the "equal numbers" provision of the rgrr Act was no longer in force. Four of the Justices-Brandeis, Stone, Roberts, and Cardozo-agreed in the result but wanted the complaint dismissed for want of equity. See Bowman, Congressional Redistricting and the Constitution, 3 I Mick. L. REv. I49, x68 (1932). See also the highly useful work, to which I am much indebted, L. F. Schmeckebier, Congressional Apportionment 145-1 49 (r94I).

${ }^{60}$ Colegrove v. Green, 328 U. S. 549 (1946). This was an attempt to have the notoriously unfair Illinois Congressional district arrangement declared invalid. Despite the fact that one district had something like nine times as many people as another, the Court refused to intervene but only by a 4-3 vote. See the excellent note, Constitutional Right to Congressional Districts of Equal Population, 56 YALE L. J. I27 (1946).

In Smiley v. Holm, 285 U. S. 355 (1932), the Supreme Court did intervene to reverse a Minnesota court's refusal to declare invalid a districting act which the governor of the state had not approved as ordinarily required. The Minnesota court procceded on the theory that since the Constitution authorized action by the state "legislature," the governor's approval was unnecessary. The Supreme Court answered that the term "legislature," as used in Art. IV, \$r, referred to the legislative power of the state however it might be distributed. See also Davis v. Hildebrant, 24 I. S. 65 (I9I6) and Bowman, stupra, note 55 . 
fairness; that a state legislature which is itself unrepresentative cannot be expected to district equitably; and that experience has indicated that Congress, for a variety of reasons, will not provide a remedy. In these circumstances, it is argued, invocation of the political processes is obviously futile. It is precisely because of the subversion of these processes that the complainants seek judicial relief.

Nevertheless, the Supreme Court has been unwilling to intervene even though confronted with an apportionment act odious to the entire Court. Two factors have largely been determinative of the Court's attitude: (I) the inability of the Court to do more than upset a particular districting act and force an election at large; and (2) the Court's conviction that Congress has the duty under the Constitution of keeping itself truly representative.

It must be admitted that the remedy available to the Court is of limited efficacy. An election at large would be totally subversive of the district idea. It would deprive sizable minorities of any representation and also distinct localities. In large states like New York and Illinois, the average voter would be overwhelmed by the sheer length of the ballot. It would be well nigh impossible for him to distinguish among so many candidates, most of whom he could hardly be expected to identify. And even if the Court were able to handle the matter successfully, it could do so only at the price of coming "into immediate and active relations with party contests." As Mr. Justice Frankfurter has said: "The one stark fact that emerges from a study of the history of Congressional Apportionment is its embroilment in politics, in the sense of party contests and party interests." ${ }^{37}$

What, then, of the suggestion of the Court that a fair apportionment is a problem ultimately for Congress alone? The Court has given abundant proof that the suggestion is not idly made. While it has never had occasion to chart systematically the power of Congress over districting within the states, the Court has carefully refrained from suggesting any limitation. Repeatedly, it has spoken of the power conferred by Article I, Section 4 in the broadest possible terms. "The Constitution," says Mr. Justice Frankfurter, "gives ample power . . . The short of it is that the Constitution has conferred upon Congress exclusive power to secure fair representation by the States in the popular House. ..." ${ }^{28}$ And as Chief Justice Hughes has said, "Congress may supplement . . . state regulations or may substitute its own." The The expressions harmonize perfectly with the general understanding of 1787-88. The problem is one for Congress and if it is to be successfully resolved, Congress must face up to the responsibility committed to it by the Constitution.

Theoretically, the scheme of the Constitution is a sound one. But its availability has been minimized by the appearance of national political parties-a development with which the framers failed to reckon. Yet, according full weight to this factor, the plan of the Constitution retains its validity. Congress, it is true, has been unable

\footnotetext{
${ }^{57}$ Colegrove v. Green, supra note 56, at 554 .

${ }^{58}$ Ibid.

${ }^{59}$ Smiley v. Holm, 285 U. S. $355,366-367$.
} 
to act in specific cases when personal and partisan considerations were immanent. But when calmly reflecting on the requisites of a fair representation, it has repeatedly asserted itself. It has done away with the general-ticket system almost entirely. It has called for Congressional districts of compact territory containing approximately equal numbers. The great difficulty has arisen, not from Congressional indifference, but rather from the lack of appropriate sanctions. Under the legislation thus far, the only tool of enforcement has been the House's privilege of refusing to seat a member from a district not conforming to Congressional standards. It would be a mistake to suppose that the political factor alone has been responsible for the House's unwillingness to resort to this extreme. There has been an understandable reluctance to deny any representation at all in order to effectuate the Congressional policy. Moreover, election contests are necessarily prolonged with the result that the challenged member may well have served much of his term by the time the investigation is complete and the House is ready to act. And it may be that any action will come too late for the state legislature involved to take corrective measures which will apply to the next election.

If Congress once again should undertake to legislate on Congressional districts, it is imperative that it provide a new mechanism to make its will effective. The best guide in this respect is the automatic feature of the 1929 Act. By providing in advance for a determination of the number of representatives to which each state is entitled, the useless struggles after each census have been avoided. The same principle could be applied to districts which failed to conform to specific standards set by Congress. Delinquent states could be identified by an official who would make purely mathematical calculations. He could, if Congress so authorized, then proceed to hold Congressional elections on a plan approved by Congress and held in reserve for just such an occasion. Under such compulsion, the states would almost certainly accept and honor the responsibility which the Constitution invites them to share. And Congress, by providing it, would be insuring to the House of Representatives its constitutional role of "grand depository of the democratic principle." 